\title{
ACUTE EFFECT OF SODIUM BICARBONATE SUPPLEMENTATION BY RESISTANT TRAINING PRACTICES
}

\author{
EFEITO AGUDO DA SUPLEMENTAÇÃO DE BICARBONATO DE SÓDIO POR \\ PRATICANTES DE TREINAMENTO DE RESISTENNCIA
}

\author{
Fanny Gonçalves de LIMA ${ }^{1}$; Thiago Montes FIDALE ${ }^{1,2}$; Gisvânia Dayane Ferreira SILVA ${ }^{3}$; \\ Mário Marcos de FARIA ${ }^{3}$; EImiro Santos RESENDE ${ }^{1}$; \\ Luiz Duarte De Ulhôa ROCHA JÚNIOR ${ }^{1}$; Marcelo COSTA JUNIOR ${ }^{1,3}$ \\ 1. Universidade Federal de Uberlândia - UFU - Uberlândia/MG, Brasil; 2. Universidade Federal de Goiás - Regional Catalão - UFG- \\ RC, Catalão, GO, Brasil; 3. Faculdade Presidente Antônio Carlos de Uberlândia -UNIPAC - Uberlândia, MG, Brasil. \\ fannylima08@hotmail.com
}

\begin{abstract}
Currently, the use of sodium bicarbonate (SB) as an ergogenic supplement has been linked to improved performance in several high-intensity and short time interval modalities because it is a natural buffer of the body fluids of the human body. This study aimed to evaluate the acute effect of SB supplementation on muscle strength endurance of resistance training practitioners. Crossover clinical trial, placebo-controlled (PL), and single-masked, included 10 trained adult men. The maximum repetition (1RM) and exhaustion tests with $80 \% 1 \mathrm{RM}$ were performed in the extensor chair and direct thread. In all sessions, the volunteers were verbally stimulated, the total maximum repetitions in the exercises and the blood lactate concentration were measured. SB was supplemented at a dose of $0.3 \mathrm{~g} / \mathrm{kg}$ body mass. Statistical analysis was performed using SPSS version 25.0. The Shapiro-Wilk test was used to evaluate the normality of the data, and the Student's t-test was used for independent and paired samples. The size of the Cohen's effect was calculated, and the significance level was set at $p<0.05$. Comparing the supplements, no significant differences were found in all variables tested. However, when comparing pretest and posttest periods, significant differences were found between lactate concentrations, with considerably large effect sizes $(>1.00)$. SB supplementation by endurance training practitioners induces blood alkalosis, which reduces fatigue and possibly improves muscle strength endurance.
\end{abstract}

KEYWORDS: Resistance Exercise. Ergogenic. Metabolic Acidosis. Muscle Fatigue.

\section{INTRODUCTION}

Currently, the supporters of physical exercises and athletes have been searching for supplements with ergogenic effects to improve their performance during trainings and/or competitions (OLIVEIRA; VIEIRA, 2019). In this sense, some authors believe that sodium bicarbonate (SB) supplementation can be an effective strategy for improving performance, as it increases the hydrogen potential $(\mathrm{pH})$ values during exercise, enabling new chemical reactions, allowing the increase of muscle contraction power since it restores the hydrogen $\left(\mathrm{H}^{+}\right)$and lactate ions $\left(\mathrm{La}^{-}\right)$production in the active muscle (SIEGLER et al., 2010).

Additionally, the supplemented SB can increase the tamponade capacity in the blood generated by high-intensity exercise as it is an alkaline substance that acts as a natural buffer and induces blood alkalosis, thereby delaying fatigue and improving performance during exercise (PRICE; SIMONS, 2010; CRIVELARO, 2012). The metabolic acidosis process occurs in high-intensity exercises, because together with lactate accumulation, there is a great release of $\mathrm{H}^{+}$ions that decreases the blood $\mathrm{pH}$ level and produces lactic acid. This $\mathrm{H}^{+}$ions' intramuscular concentration inhibits the glycolytic enzymes and depreciates the contraction action leading to muscle fatigue and performance drop during exercise (SILVA, 2016).

The $\mathrm{H}^{+}$ions' concentration is of paramount significance for the vital function of some organs, and the imbalance between the formation and consumption of $\mathrm{H}^{+}$ions can lead to metabolic acidosis and loss of homeostasis of the organism. In this case, the first mechanism triggered for regulation is the buffer system of the body liquids, where the buffer can be understood as a substance capable of making reversible connection with the $\mathrm{H}^{+}$ ions. Thus, the body has three known systems for regulating this balance-the acid-base chemical buffer systems of the body fluids, the respiratory center, and the kidneys (GUYTON; HALL, 2017).

The intramuscular accumulation of the $\mathrm{H}^{+}$ ions can further lead to peripheral muscle fatigue by reducing the skeletal muscle contractile strength to 
the extent that it limits the muscle to generate tension. The $\mathrm{H}^{+}$ions accumulated in the muscle tissue compete with the calcium ions $\left(\mathrm{Ca}^{2+}\right)$, which are the beacons for muscle contraction, to make connections at the specific site in the troponin. Since the $\mathrm{H}^{+}$ion binds to this site, it inhibits the removal of tropomyosin, thus preventing the cross-bridge activation and sliding the actin on the myosin head (SILVERTHORN, 2017).

Currently, SB has been used as an ergogenic substance for performing chemical tamponade and inducing blood alkalosis, and a dose of $0.3 \mathrm{~g} / \mathrm{kg}$ body mass is the most indicated to improve performance without causing gastrointestinal system damage (CAMERON et al., 2010; CARR et al., 2011; CORREIA-OLIVEIRA; KISS, 2017; DERISSO et al., 2014; HIGGINS; JAMES; PRICE, 2013; PEART; SIEGLER; VINCE, 2012), to improve average power and performance in highintensity exercises, and to delay fatigue during predominant anaerobic exercises (DUNCAN; WELDON; PRICE, 2014).

Several studies have addressed the effects of the use of SB as an ergogenic substance in highintensity exercises and in cyclical and intermittent sports, such as rowing, running, cycling, swimming, and judo (ARTIOLI et al., 2007; EGGER et al., 2014; FELIPPE et al., 2016; HEIBEL et al., 2018; ZAJAC et al., 2009), in which resistance training is performed in a lower proportion (CARR et al., 2013; OLIVEIRA JÚNIOR, 2016; PORTINGTON et al., 1998).

The possible benefits of the SB supplementation were not found some studies (CAMELO, 2018; FLINN et al., 2014; GAITANOS et al., 1991; MENDES et al., 2015). Thus, despite the large number of studies, SB indication as an ergogenic substance still has no scientific merit and the recommendation of use in resistance training remains controversial.

Therefore, the research shows its relevance because it is a current theme and with a growing demand of physical exercise and athletes practitioners for supplements with ergogenic effects, in an attempt to improve performance during training and/or competitions. The present study aimed to evaluate the acute effect of SB on the muscle strength endurance of resistance training practitioners.

\section{MATERIAL AND METHODS}

Study design
The randomized placebo-controlled
crossover clinical trial (PL) and single-blind

masking were the study designs utilized, and the participants were randomized by lot and randomly allocated to groups. Group 1: first test - PL + interval + test $-\mathrm{SB}$ and group 2 : test $-\mathrm{SB}+$ interval + test - PL.

\section{Sample}

Convenience sample and included 10 volunteers who completed all the tests. Were included in the research trained adult men more than two years ago and at least six months of uninterrupted practice, with moderate-to-intense in intensity aged between 20 and 40 years. Adult men, aged between 20 and 40 years, training sportsmen resisted for more than two years, with moderate-tointense training and at least six months of uninterrupted practice, were included in the research.

Individuals who used some type of ergogenic supplement in the last six months and who presented health restriction that limited the exercise practice, thereby making it impossible to perform the tests, were excluded from the study.

Among the fifteen volunteers who met the eligibility criteria, five did not finish the tests, three attended only on the first day, and two attended on the first and second day however did not complete the last test because they were injured.

\section{Ethical Considerations}

The study was approved by the Human Research Ethics Committee of the Federal University of Uberlândia-UFU (protocol No: 337/11). All individuals who agreed to participate signed the Informed Consent Form, prepared in accordance with Resolution CNS 466/12, authorizing their participation. The volunteers received guidance on the procedures to be performed, the benefits and possible risks of the research.

\section{Intervention}

The study consisted of three meetings for data collection, with an interval of one week for physical recovery of the volunteers, always setting the same time and day of the week. The volunteers were instructed not to perform exhaustive physical exercise, and to eat and hydrate properly on the test days.

In the first meeting, anthropometric data were collected, such as: body mass $(\mathrm{Kg})$, height (m), and the one repetition maximum (1RM) test. According to Custódio et al. (2011), the 1RM corresponds to the maximum weight value raised by the individual at once in a given exercise. 
Acute effect...

The determination of the maximum load $1 \mathrm{RM}$ was calculated by means of five attempts in each exercise, with an interval of three to five minutes, until the load in $\mathrm{Kg}$ indicative of a single maximum repetition (ALVES et al., 2018) was obtained. The load adjustment between attempts was performed with the subjective perception of effort of the individual, according to the Modified Borg Scale (zero to 10) (BORG, 1982, 1998).

In the second and third data collection meeting, the exhaustion test was performed with $80 \%$ of 1 RM (ALVES et al., 2018; PORTO et al., 2008). Furthermore, the number of maximum repetitions was determined by fatigue, or maximum voluntary exhaustion, with inability to sustain the continuous pattern of movement, and the blood lactate dosage pretest and posttest was also collected.

In the exhaust tests, eight series were performed with maximum repetition until the failure in the exercises: extensor chair (four series) and direct thread (four series). In all sessions, the volunteers were verbally stimulated, and the total maximal repetitions were computed in both exercises. The recovery interval between the series was $90 \mathrm{sec}$.

Study volunteers ingested blindly thirty minutes before the test (JONES et al., 2016), SB supplementation or PL, following the crossover model, according to randomization by draw and allocation in the groups. The SB was administered at a dose of $0.3 \mathrm{~g} / \mathrm{kg}$ body mass, and to mask the flavor and mitigate the gastrointestinal discomfort caused by it in some individuals, maltodextrin carbohydrate was used (DOS SANTOS MOTTA; DE SOUZA, 2018; PRICE; CRIPPS, 2012). Further, maltodextrin was used as the placebo (SAUNDERS et al., 2014a) and was administered at the same dose as SB.

\section{Lactate analysis}

The blood lactate analysis was performed on the days of exhaustion tests, being collected at rest (pretest), and immediately after the last series (posttest). A porTable lactometer (Accutrend Plus Roche ${ }^{\circledR}$ ) and reagent strips (Accusport BM Lactate)
LIMA, F. G. et al.

were used with a lancet with disposable microlancets for puncture, succedingly collecting two drops of blood from the distal phalanx from one of the nondominant fingers of the volunteer.

\section{Statistical Analysis}

The statistical analysis was performed using the statistical program Statistical Package for the Social Sciences 25.0 (SPSS Inc., Chicago, IL, USA). Descriptive statistics was used to characterize the participants' data and used as a measure of central to medium tendency and as a dispersion the standard deviation. The Shapiro-Wilk test was used to evaluate data normality, and the $p$ was found equal to 0.57 ; therefore, the data was treated as normal. The Student's t-test for the independent samples was used to compare the means of the variable difference between pretest and posttest lactacidemia, lactacidemia, and number of repetitions before and after the test, according to the supplementation used. The Student's t-test for the paired samples was used to compare the serum lactate concentration between the pre and posttest periods. For all the comparisons where significant differences were found, the Cohen effect size (COHEN, 1992) was calculated, and a magnitude measure of differences where values below 0.20 are considered small and above 0.80 as large. In addition, the level of significance adopted for the present investigation was $\mathrm{p}<0.05$.

\section{RESULTS}

The experimental study had the participation of trained adult men, more than two years ago and at least six months of uninterrupted practice, with moderate-to-intense in intensity. The volunteers have not used ergogenic supplementation in the last six months leading up to the tests. Furthermore, the characteristics of the individuals analyzed included the age, which ranged from 29 to 36 years, the mean height of $1.74 \mathrm{~m}$, and the mean weight of $87.28 \mathrm{~kg}$. The weight average in $\mathrm{kg}$ supported in a maximum repetition (1RM) in the and extensor chair as well as in the direct thread was described in Table 1 below.

Table 1. Sample description: Anthropometric data and the 1RM value

\begin{tabular}{ll}
\hline Features & Mean \pm SD \\
\hline Age (years) & $29.00 \pm 7.39$ \\
Height (m) & $1.74 \pm 0.10$ \\
Weight (kg) & $87.28 \pm 20.53$ \\
Extensor Chair (1RM) kg & $97.50 \pm 22.01$ \\
Direct Thread (1RM) kg & $43.30 \pm 8.99$ \\
\hline
\end{tabular}

Source: Elaborated by the authors 
Comparing the placebo and bicarbonate supplements, no significant differences ( $p>0.05)$ are found in all tested variables: difference between the pre and posttest lactacidemia, pretest lactacidemia, posttest lactacidemia, and number of repetitions (Table 2).

Table 2. Comparison between supplementation by Student's t-test for independent samples

\begin{tabular}{llllll}
\hline \multicolumn{7}{l}{ Supplementation } \\
\hline Variables - Medium (+Standard deviation) & Placebo & \multicolumn{3}{l}{ Bicarbonate } & P value \\
Difference between pre and posttest lactacidemia & 4,88 & $(2,79)$ & 5,11 & $(4,33)$ & 0,88 \\
Lactacidemia pretest (mmol/L) & 3,72 & $(1,66)$ & 4,07 & $(2,41)$ & 0,71 \\
Posttest lactacidemia (mmol/L) & 8,60 & $(2,75)$ & 9,18 & $(4,50)$ & 0,73 \\
Number of repetitions & 64,60 & $(10,61)$ & 67,70 & $(15,59)$ & 0,61 \\
\hline
\end{tabular}

Source: Elaborated by the authors.

In the comparison between the pretest and posttest periods, significant differences were found between lactate concentrations, with considerably large Cohen effect sizes $(>1.00)$ as shown in Table 3.

Table 3. Comparison between supplementation by Student's t-test for paired samples

\begin{tabular}{llllllll}
\hline & Pretest lactacidemia $(\mathrm{mmol} / \mathrm{L})$ & Posttest lactacidemia $(\mathrm{mmol} / \mathrm{L})$ & $\mathrm{P}$ & Cohen & effect \\
\cline { 1 - 5 } Supplementation: & Average & Standard deviation & Average & Standard deviation & value & size & \\
Placebo & 3,72 & 1,66 & 8,60 & 2,75 & 0,00 & 2,15 & \\
Bicarbonate & 4,07 & 2,41 & 9,18 & 4,50 & 0,00 & 1,42 & \\
\hline
\end{tabular}

Source: Elaborated by the authors.

\section{DISCUSSION}

The aim of this study was to analyze the acute effect of the SB supplementation on the muscle strength resistance of endurance practitioners. The individuals analyzed were submitted to exhaustion tests with $80 \%$ of $1 \mathrm{RM}$ and a comparison was made between the supplementation with PL and SB.

When we analyzed the supplementation comparison with PL and SB, we found out that the differences were not significant $(p>0.05)$ in all the tested variables (Table 2). Furthermore, similar findings were noted in other studies (CAMELO, 2018; MENDES et al., 2015), wherein no benefit results and ergogenic efficacy of SB supplementation were found.

The study by Heibel et al. (2018) states that the ergogenic effect of SB intake is dependent on individual responses and suggests that supplementation should be done so that exercise is performed at the maximum bicarbonate concentration to increase the opportunities for improved performance and that the side effects should be nonexistent or minimized. Thus, we assume that although no volunteer in the present study has a side effect, the small sample may have minimized the results of the supplementation.

In the current study, there was a higher lactate concentration in the posttest period, both in the SB and placebo supplementations (Table 3). Previous studies corroborate the data of the present research, demonstrating that the resistance training promotes a significant increase in the blood lactate in the postexercise period (GENTIL et al., 2006; JÚNIOR; ALVES, 2013; SIQUEIRA et al., 2018). Hence, lactate can be used as a physiological marker for prescribing training in resistance exercises (MEIRELLES; WERLANG-COELHO, 2018).

In high-intensity physical exercise and with a short time interval, as in the case with resistance training, the anaerobic metabolic pathway (glycolytic), where the main energy substrate is glucose, is prioritized. In the anaerobic glycolysis, the glucose breaks out to produce energy (ATP) to sustain exercise and lactate (POWERS; HOWLEY, 2014).

The lactate produced in this metabolic pathway is used to buffer the $\mathrm{H}^{+}$ions, formed in the process of substrate degradation in glycolysis reactions, consequently transformed into lactic acid. However, the amount of $\mathrm{H}^{+}$ions exceeds the lactate production, reducing the buffering capacity of the same, with an accumulation of $\mathrm{H}^{+}$ions in the muscle cell with reduction in $\mathrm{pH}$, with a reduction in the capacity of maximum muscle strength generation (ROBERGS, 2017).

According to the results obtained in the present study, SB served as a buffer, reacting with $\mathrm{H}^{+}$ions, causing $\mathrm{pH}$ to return its normality, because 
we found a higher lactate concentration at the time of SB supplementation (Table 3), signaling that the glycolytic pathway reoccurred and produce more energy (ATP) and more lactate, due to metabolic alkalosis.

According to Carr et al. $(2011 ; 2013)$ and Deb et al. (2017), this may be the explanation for the significant increase in blood lactate postexercise in individuals who underwent supplementation with SB, suggesting greater energy contribution and improved performance in the proposed exercise.

Results similar to that of the present study where lactate dosage is higher in post-exercise with SB supplementation, are evidenced in the literature review of Sahlin (2014). The author finds data to support that nutritional strategies, such as SB supplementation, can improve anaerobic capacity by increasing $\mathrm{pH}$ and avoiding acidosis, with the expectation of augmenting the patient's ability to generate force, thereby allowing increased training load.

In the meta-analysis of Christensen et al. (2017) 33 performance tests demonstrated improved performance after SB supplementation compared to the placebo. A SB dose of $0.3 \mathrm{~g} / \mathrm{kg}$ body mass is also considered the most effective means to improve the performance of high-intensity exercises, when compared it with other nutritional strategies in order to increase intra and extracellular buffer capacity (JUNIOR et al., 2015).

In higher blood lactate with SB intake, they can be an effect of increased fatigue resistance, thus, greater glycolytic contribution and concomitant production of muscle lactate (MARRIOTT;
KRUSTRUP; MOHR, 2015). The current study presented results consistent to the studies mentioned above because the use of the $0.3 \mathrm{~g} / \mathrm{kg}$ body mass dose administered $30 \mathrm{~min}$ before the test showed efficiency; there was higher lactate production with use SB supplementation $(9.18 \pm 4.5 \mathrm{mmol})$ than with the use of PL $(8.6 \pm 2.75 \mathrm{mmol})$.

Leading us to believe that there may also be a small improvement in muscle strength resistance of resistance training practitioners analyzed, because the current study presented a higher number of repetitions $(67.70 \pm 15.59)$ in $\mathrm{SB}$ supplementation when compared to the PL $(64.60 \pm 10.61)$, although $\mathrm{p}=0.61$. Although some studies within the theme also present a similar number of samples, we believe that the results could be potentiated, with more relevant statistical significance if the number of volunteers were higher, this being a limitation of the study.

\section{CONCLUSION}

We conclude that SB supplementation by resistance training practitioners results in a higher lactate concentration posttest, indicating possible blood alkalosis, which slows fatigue in training that requires high intensity and short time, and possible improvement in the endurance muscle strength and greater number of repetitions. Further, this study provides positive insights into the topic and suggests further studies to better analyze the acute effects of supplementation so that $\mathrm{SB}$ can be used as a proven ergogenic nutritional supplement without causing health damages in the future.

RESUMO: Atualmente, o uso de bicarbonato de sódio (SB) como suplemento ergogênico tem sido associado a um melhor desempenho em várias modalidades de alta intensidade e intervalos de tempo curtos, pois é um amortecedor natural dos fluidos corporais do corpo humano. Este estudo teve como objetivo avaliar o efeito agudo da suplementação de SB na resistência da força muscular de praticantes de treinamento de resistência. Ensaio clínico cruzado, controlado por placebo (PL) e com máscara única, incluiu 10 homens adultos treinados. Os testes de repetição máxima (1RM) e exaustão com $80 \%$ de $1 \mathrm{RM}$ foram realizados na cadeira extensora e na rosca direta. Em todas as sessões, os voluntários foram estimulados verbalmente, foram medidas as repetições máximas totais nos exercícios e a concentração de lactato sanguíneo. O SB foi suplementado na dose de $0,3 \mathrm{~g} / \mathrm{kg}$ de massa corporal. A análise estatística foi realizada no SPSS versão 25.0. O teste Shapiro-Wilk foi usado para avaliar a normalidade dos dados, e o teste $t$ de Student foi usado para amostras independentes e emparelhadas. O tamanho do efeito de Cohen foi calculado e o nível de significância foi estabelecido em $\mathrm{p}<0,05$. Comparando os suplementos, não foram encontradas diferenças significativas em todas as variáveis testadas. No entanto, ao comparar os períodos pré e pós-teste, foram encontradas diferenças significativas entre as concentrações de lactato, com tamanhos de efeito consideravelmente grandes $(>1,00)$. A suplementação de SB por praticantes de treinamento de resistência induz alcalose no sangue, o que reduz a fadiga e possivelmente melhora a resistência da força muscular.

PALAVRAS-CHAVE: Exercício Resistido. Ergogênico. Acidose Metabólica. Fadiga Muscular. 


\section{REFERENCES}

ALVES, R. C.; PRESTES, J; BUENO, J. C. A.; DEL VECCHIO, F. B.; SOUZA JUNIOR, T. Comparação do gasto energético em diferentes métodos do treinamento de força. ConScientiae Saúde, v. 17, n. 3, p. 293-301, 2018. Available in: https://www.researchgate.net/publication/328414964. Access in:13 nov. 2018. https://doi.org/10.5585/conssaude.v17n3.8288

ARTIOLI, G. G.; GUALANO, B.; FERREIRA COELHO, D.; BRAGA BENATTI, F.; WHYTE GAILEY, A.; HEBERT LANCHA, A. JR. Does sodium-bicarbonate ingestion improve simulated judo performance?

International journal of sport nutrition and exercise metabolism, v. 17, n. 2, p. 206-217, 2007. Available in: https://www.ncbi.nlm.nih.gov/pubmed/17507744 . Access in:13 nov. 2018.

https://doi.org/10.1123/ijsnem.17.2.206

BORG, G. A. Psychophysical bases of perceived exertion. Med sci sports exerc, v. 14, n. 5, p. 377-381, 1982. Available in: https://www.ncbi.nlm.nih.gov/pubmed/7154893 . Access in:13 nov. 2018.

https://doi.org/10.1249/00005768-198205000-00012

BORG, G. Borg's perceived exertion and painscales. Stockholm: Human Kinetics, 1998.

CAMELO, W. O. Análise do lactato sanguíneo e o efeito da ingestão de bicarbonato de sódio no exercício resistido e pliométrico. 2018. Available in: https://repositorio.uniceub.br/jspui/handle/235/12271. Access in:13 nov. 2018.

CAMERON, S. L.; MCLAY-COOKE, R. T.; BROWN, R. C.; GRAY, A. R.; FAIRBAIRN, K. A. Increased blood $\mathrm{pH}$ but not performance with sodium bicarbonate supplementation in elite rugby union players.

International Journal of Sport Nutrition and Exercise Metabolism. Dunedin. Vol. 20. Num. 4. 2010. p. 307-321. Available in: https://www.ncbi.nlm.nih.gov/pubmed/20739719 . Access in:13 nov. 2018. https://doi.org/10.1123/ijsnem.20.4.307

CARR, A. J.; HOPKINS, W. G.; GORE, C. J. Effects of acute alkalosis and acidosis on performance. Sports medicine, v. 41, n. 10, p. 801-814, 2011. Available in: https://doi.org/10.2165/11591440-000000000-00000. Access in:13 nov. 2018.

CARR, B. M.; WEBSTER, M. J., BOYD, J. C., HUDSON, G. M.; SCHEETT, T. P. Sodium bicarbonate supplementation improves hypertrophy-type resistance exercise performance. European journal of applied physiology, v. 113, n. 3, p. 743-752, 2013. Available in: https://www.ncbi.nlm.nih.gov/pubmed/22941193 . Access in:13 nov. 2018. https://doi.org/10.1007/s00421-012-2484-8

CHRISTENSEN, P. M.; SHIRAI, Y.; RITZ, C.; NORDSBORG, N. B. Caffeine and bicarbonate for speed. A meta-analysis of legal supplements potential for improving intense endurance exercise performance. Frontiers in physiology, v. 8, p. 240, 2017. Available in:https://www.frontiersin.org/articles/10.3389/fphys.2017.00240/full\#B117. Access in:13 nov. 2018. https://doi.org/10.3389/fphys.2017.00240

COHEN, J. Statistical power analysis. Current directions in psychological science, v. 1, n. 3, p. 98-101, 1992. https://doi.org/10.1111/1467-8721.ep10768783

CORREIA-OLIVEIRA, C. R.; KISS, M. A. P. Dal'M. Alcalose metabólica induzida por bicarbonato de sódio: mecanismos de ação, dose utilizada e efeitos sobre o desempenho em ciclismo de alta intensidade. Revista Brasileira de Ciência e Movimento, v. 25, n. 3, p. 169, 2017. Available in: https://www.rbne.com.br/index.php/rbne/article/viewFile/318/305 . Access in:13 nov. 2018.

CRIVELARO, P. Influência da suplementação de bicarbonato de sódio no desempenho anaeróbio em atletas de futebol. Revista Brasileira de Nutrição Esportiva. São Paulo. v. 6, n. 33, p. 215-222, Maio/Jun. 2012. ISSN 1981-9927. Available in: https://www.rbne.com.br. Access in:13 nov. 2018. 
CUSTÓDIO, D.; MIR, F. E.; ZAMBONATO, P. D.; LIBERALI, R. Efeitos de um programa contra resistência com pesos sobre a força muscular. RBPFEX-Revista Brasileira de Prescrição e Fisiologia do Exercício, v. 2, n. 12, 2011. Available in: https://www.rbpfex.com.br/index.php/rbpfex/article/viewFile/132/134 . Access in:13 nov. 2018.

DEB, S. K.; GOUGH, L. A.; SPARKS, S. A.; MCNAUGTON, L. R. Determinants of curvature constant (W') of the power duration relationship under normoxia and hypoxia: the effect of pre-exercise alkalosis. European journal of applied physiology, v. 117, n. 5, p. 901-912, 2017. Available in:

https://www.ncbi.nlm.nih.gov/pubmed/28280973. Access in:13 nov. 2018. https://doi.org/10.1007/s00421017-3574-4

DERISSO, E. M.; MOTOYMA, Y. L.; PEREIRA, P. E. A.; AZEVEDO, P. H. S. M.; JESUS, G. E.; BOTERO, J. P. Efeitos da suplementação de bicarbonato de sódio em um teste ergométrico de esforço crescente em homens recreacionalmente ativos. RBNE-Revista Brasileira de Nutrição Esportiva, v. 8, n. 43, 2014. Available in: http://www.rbne.com.br/index.php/rbne/article/view/392/395. Access in:13 nov. 2018.

DOS SANTOS MOTTA, E.; DE SOUZA, E. B. Suplementação de bicarbonato de sódio em praticantes de musculação. Revista Brasileira de Nutrição Esportiva, v. 12, n. 74, p. 812-818, 2018. Available in: http://www.rbne.com.br/index.php/rbne/article/view/1144 . Access in:13 nov. 2018.

DUNCAN, M. J.; WELDON, A.; PRICE, M. J. The effect of sodium bicarbonate ingestion on back squat and bench press exercise to failure. The Journal of Strength \& Conditioning Research, v. 28, n. 5, p. 1358-1366, 2014. Available in: http://dx.doi.org/10.1519/JSC.0000000000000277. Access in:13 nov. 2018.

EGGER, F.; MEYER, T.; SUCH, U.; HECKSTEDEN, A. Effects of sodium bicarbonate on high-intensity endurance performance in cyclists: a double-blind, randomized cross-over trial. PloS one, v. 9, n. 12, p. e114729, 2014. Available in: https://europepmc.org/abstract/med/25494054 . Access in:13 nov. 2018. https://doi.org/10.1371/journal.pone.0114729

FELIPPE, L.; LOPES-SILVA, J. P.; BERTUZZI, R.; MCGINLEY, C.; LIMA-SILVA, A. E. Separate and combined effects of caffeine and sodium-bicarbonate intake on judo performance. International journal of sports physiology and performance, v. 11, n. 2, p. 221-226, 2016. Available in:

https://www.ncbi.nlm.nih.gov/pubmed/26182440 . Access in:13 nov. 2018. https://doi.org/10.1123/ijspp.20150020

FLINN, S.; HEBERT, K; GRAHAM, K; SIEGLER, J. C. Differential effect of metabolic alkalosis and hypoxia on high-intensity cycling performance. The Journal of Strength \& Conditioning Research, v. 28, n. 10, p. 2852-2858, 2014. Available in: https://www.ncbi.nlm.nih.gov/pubmed/24983849 . Access in:13 nov. 2018. https://doi.org/10.1519/JSC.0000000000000489

GAITANOS, G. C.; NEVILL, M. E.; BROOKS, S.; WILLIAMS, C. Repeated bouts of sprint running after induced alkalosis. Journal of sports sciences, v. 9, n. 4, p. 355-370, 1991. Available in:

https://doi.org/10.1080/02640419108729896. Access in:13 nov. 2018.

GENTIL, P.; ELKE, O.; FONTANA, K.; MOLINA, G.; OLIVEIRA, R. J.; BOTTARO, M. Efeitos agudos de vários métodos de treinamento de força no lactato sanguíneo e características de cargas em homens treinados recreacionalmente. Rev bras med esporte, v. 12, n. 6, p. 303-7, 2006. Available in:

http://dx.doi.org/10.1590/S1517-86922006000600001. Access in:13 nov. 2018.

GUYTON, A. C.; HALL, J. E. Tratado de Fisiologia Médica. 13ª ed. Rio de Janeiro, Elsevier Ed., 2017.

HEIBEL, A. B.; PERIM, P. H. L.; OLIVEIRA, L. F.; MCNAUGHTON, L. R.; SAUNDERS, B. Time to Optimize Supplementation: Modifying Factors Influencing the Individual Responses to Extracellular Buffering Agents. Frontiers in nutrition, v. 5, 2018. Available in: https://www.ncbi.nlm.nih.gov/pubmed/29868599. Access in:13 nov. 2018. https://doi.org/10.3389/fnut.2018.00035 
HIGGINS, M. F.; JAMES, R. S.; PRICE, M. J. The effects of sodium bicarbonate (NaHCO3) ingestion on high intensity cycling capacity. Journal of sports sciences, v. 31, n. 9, p. 972-981, 2013. Available in: https://www.ncbi.nlm.nih.gov/pubmed/23323673. Access in:13 nov. 2018. https://doi.org/10.1080/02640414.2012.758868

JONES, R. L.; STELLINGWERFF, T.; ARTIOLI, G. G.; SAUNDERS, B.; COOPER, S.; SALE, C. Doseresponse of sodium bicarbonate ingestion highlights individuality in time course of blood analyte responses. International journal of sport nutrition and exercise metabolism, v. 26, n. 5, p. 445-453, 2016. Available in: https://doi.org/10.1123/ijsnem.2015-0286. Access in:13 nov. 2018.

JÚNIOR, R.; ALVES, A. Análise do lactato sanguíneo em exercício resistido. 2013. Available in: https://repositorio.uniceub.br/handle/235/970 . Access in:13 nov. 2018.

JUNIOR, A. H. L.; PAINELLI, V. S.; SAUNDERS, B.; ARTIOLI, G. G. Nutritional strategies to modulate intracellular and extracellular buffering capacity during high-intensity exercise. Sports Medicine, v. 45, n. 1, p. 71-81, 2015. Available in: https://link.springer.com/content/pdf/10.1007\%2Fs40279-015-0397-5.pdf. Access in:13 nov. 2018. https://doi.org/10.1007/s40279-015-0397-5

MARRIOTT, M.; KRUSTRUP, P.; MOHR, M. Ergogenic effects of caffeine and sodium bicarbonate supplementation on intermittent exercise performance preceded by intense arm cranking exercise. Journal of the International Society of Sports Nutrition, v. 12, n. 1, p. 13, 2015. Available in: https://jissn.biomedcentral.com/articles/10.1186/s12970-015-0075-x . Access in:13 nov. 2018. https://doi.org/10.1186/s12970-015-0075-x

MENDES, E. L.; JUNIOR, R. A.; ANDAKI, A. C. R.; JUNIOR, M. M.; SIMIM, M. A. M.; MOTA, G. R. Ergogênicos nutricionais e desempenho no rugby: revisão sistemática. Arquivos de Ciências do Esporte, v. 2, n. 1, 2015. Available in: http://seer.uftm.edu.br/revistaeletronica/index.php/aces/article/view/348 . Access in: 13 nov. 2018.

MEIRELLES, L. A.; WERLANG-COELHO, C. Produção de lactato em diferentes níveis de aptidão na execução de exercício na cadeira extensora. RBPFEX-Revista Brasileira de Prescrição e Fisiologia do Exercício, v. 12, n. 77, p. 686-693, 2018. Available in: http://www.rbpfex.com.br/index.php/rbpfex/issue/view/77 . Access in:13 nov. 2018.

OLIVEIRA, S. A.; VIEIRA, P. D. O USO DE RECURSOS ERGOGÊNICOS NUTRICIONAIS ENTRE ATLETAS OU DESPORTISTAS COM ÊNFASE EM SEU EFEITO PLACEBO: Uma revisão integrativa. Revista E-Ciência, v. 6, n. 2, 2019. Available in: http://www.revistafjn.com.br/revista/index.php/eciencia/article/view/347. Access in:13 nov. 2018. https://doi.org/10.19095/rec.v6i2.347

OLIVEIRA JÚNIOR, G. A. de. Avaliação dos efeitos do uso de bicarbonato de sódio no lactato sanguíneo ao realizar exercício de agachamento. 2016. Available in: https://repositorio.uniceub.br/handle/235/8917. Access in:13 nov. 2018.

PEART, D. J.; SIEGLER, J. C.; VINCE, R. V. Practical recommendations for coaches and athletes: a metaanalysis of sodium bicarbonate use for athletic performance. The Journal of Strength \& Conditioning Research, v. 26, n. 7, p. 1975-1983, 2012. Available in: https://journals.lww.com/nscajscr/Pages/articleviewer.aspx?year=2012\&issue=07000\&article=00032\&type=Fulltext. Access in:13 nov. 2018. https://doi.org/10.1519/JSC.0b013e3182576f3d

PORTINGTON, K. J.; PASCOE, D. D.; WEBSTER, M. J.; ANDERSON, L. H.; RUTLAND, R. R.; LIS, L. B. Effect of induced alkalosis on exhaustive leg press performance. Medicine and science in sports and exercise, v. 30, n. 4, p. 523-528, 1998. Available in: https://www.ncbi.nlm.nih.gov/pubmed/9565933 . Access in:13 nov. 2018. https://doi.org/10.1097/00005768-199804000-00009 
PORTO, M.; ORSATTI, F. L.; BORGES-SANTOS, M. D.; BURINI, R. C. Impacto do exercício muscular exaustivo sobre indicadores sanguíneos em praticantes de musculação. Rev Bras Cineantropom Desempenho Hum, v. 10, n. 3, p. 230-6, 2008. Available in: http://dx.doi.org/10.5007/1980-0037.2008v10n3p230 . Access in: 13 nov. 2018.

POWERS, S. K.; HOWLEY, E. T. Fisiologia do exercício: teoria e aplicação ao condicionamento e ao desempenho. Manole, 2014.

PRICE, M. J.; SIMONS, C. The effect of sodium bicarbonate ingestion on high-intensity intermittent running and subsequent performance. The Journal of Strength \& Conditioning Research, v. 24, n. 7, p. 1834-1842, 2010. Available in: https://www.ncbi.nlm.nih.gov/pubmed/20555273/. Access in:13 nov. 2018.

https://doi.org/10.1519/JSC.0b013e3181e06e4a

PRICE, M. J.; CRIPPS, D. The effects of combined glucose-electrolyte and sodium bicarbonate ingestion on prolonged intermittent exercise performance. Journal of sports sciences, v. 30, n. 10, p. 975-983, 2012. Available in: https://www.ncbi.nlm.nih.gov/pubmed/22616569. Access in:13 nov. 2018. https://doi.org/10.1080/02640414.2012.685086

ROBERGS, R. A. Competitive cation binding computations of proton balance for reactions of the phosphagen and glycolytic energy systems within skeletal muscle. PloS one, v. 12, n. 12, p. e0189822, 2017. Available in: https://www.ncbi.nlm.nih.gov/pubmed/29267370 . Access in:13 nov. 2018.

https://doi.org/10.1371/journal.pone.0189822

SAHLIN, K. Muscle energetics during explosive activities and potential effects of nutrition and training. Sports medicine, v. 44, n. 2, p. 167-173, 2014. Available in:

https://www.ncbi.nlm.nih.gov/pmc/articles/PMC4213384 . Access in:13 nov. 2018.

https://doi.org/10.1007/s40279-014-0256-9

SAUNDERS, B.; SALE, C.; HARRIS, R. C.; SUNDERLAND, C. Effect of sodium bicarbonate and Betaalanine on repeated sprints during intermittent exercise performed in hypoxia. International journal of sport nutrition and exercise metabolism, v. 24, n. 2, p. 196-205, 2014a. Available in:

https://www.ncbi.nlm.nih.gov/pubmed/24225816. Access in:13 nov. 2018.

https://doi.org/10.1123/ijsnem.2013-0102

SIEGLER, J. C.; MCNAUGHTON, L.; MINDGLEY, A. W.; KEATLEY, S.; HILLMAN, A. Metabolic alkalosis, recovery and sprint performance. International journal of sports medicine, v. 31, n. 11, p. 797-802, 2010. Available in: https://works.bepress.com/lars_menaughton/1/. Access in:13 nov. 2018.

https://doi.org/10.1055/s-0030-1261943

SILVA, R. P. Suplementação de beta-alanina e bicarbonato de sódio: efeitos sobre a utilização dos sistemas energéticos durante o exercício intermitente de alta intensidade. Tese de Doutorado. Universidade de São Paulo, 2016. Available in: http://www.teses.usp.br/teses/disponiveis/39/39132/tde-19102016093551/en.php . Access in:13 nov. 2018.

SILVERTHORN, D. U. Fisiologia humana: uma abordagem integrada. Artmed editora, 2017.

SIQUEIRA, L. O. C.; PRADO, M. M.; SIMIONATO, A. R.; SANCASSANI, A.; PESSÔA FILHO, D. M. Resposta aguda do lactato sanguíneo a diferentes protocolos de treinamento com pesos. Revista Brasileira de Medicina do Esporte, v. 24, n. 1, p. 26-30, 2018. Available in:

http://www.scielo.br/scielo.php?script=sci_abstract\&pid=S1517-86922018000100026\&lng=pt\&tlng=pt. Access in:13 nov. 2018. https://doi.org/10.1590/1517-869220182401173550

ZAJAC, A.; CHOLEWA, J.; POPRZECKI, S.; WASKIEWICZ, Z.; LANGFORT, J. Effects of sodium bicarbonate ingestion on swim performance in youth athletes. Journal of sports science \& medicine, v. $8, \mathrm{n}$. 1, p. 45, 2009. Available in: https://www.ncbi.nlm.nih.gov/pubmed/24150555 . Access in:13 nov. 2018. 